\title{
The Impact Of The Joint Provision Of Non-Audit Services On Audit Firm's Tenure: A Kuwaiti Evidence
}

\author{
Meshari O. Al-Hajri, Kuwait University, Kuwait
}

\begin{abstract}
Concerns about the potential harm of the increased economic bond between the audit firm and the audit client resulting from the joint provision of audit and NAS have been investigated extensively in the audit literature. However, much of this research was conducted in developed countries' settings, with very little, if any, carried out in the context of a developing country. The current study aims at filling this gap in audit research by investigating two important issues related to the joint provision using data from the Kuwaiti audit market. First, this study examines whether there is an association between the provision of NAS to the audit client and audit firm's tenure as a surrogate of audit independence. Second, the current study aims at examining factors expected to influence clients' purchase of NAS in the Kuwaiti audit market. Contrary to expectations, the results reveal a negative relationship between the joint provision and external audit firm's tenure, suggesting that such a joint provision does not lead to the impairment of auditor independence. Results obtained from the NAS purchase logistic regression also show that audit client's purchase of NAS from their audit firms is positively related to the amount of audit fees and client's financial leverage.
\end{abstract}

Keywords: Audit Tenure; Auditor Independence; Non-audit Services; Kuwait

\section{INTRODUCTION}

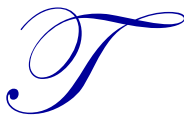

he potential impact of the joint provision of Non-Audit Services (NAS) to audit clients on auditors' independence has been a source of dispute for decades in the audit literature. This issue has attracted more attention even more in the wake of the wave of audit failures around the world during the 2000's (e.g., Enron, WorldCom, and Tyco). Moreover, the significant increase in the proportion of revenues audit firms obtain from providing NAS to audit clients during the last two decades raised some concerns about the effect of the provision of such services on auditors' independence (Levitt, 2000). Such concerns have motivated several rule-making bodies responsible for regulating the audit profession, especially in Western countries, to issue rules aimed at safeguarding auditors' independence from the possibly negative effects of providing NAS to audit clients, including the famous U.S. Sarbanes \& Oxley Act. Additionally, the joint provision issue has long attracted the interest of academics and has been a focus of investigation of extensive audit research (e.g., Simunic, 1984; Beck, Frecka, \& Solomon, 1988b; Barkess \& Simnett, 1994; Hay, Knechel, \& Li , 2006; Basioudis, Papakonstantinou, \& Geiger, 2008; Davis \& Hollie, 2008; Ye, Carson, \& Simnett, 2011; Klumpes, Komarev, \& Eleftheriou, 2016; Park, Choi, \& Cheung, 2017). This line of audit research has typically sought examining whether the joint provision of audit and NAS to audit clients can lead to jeopardizing auditors' independence.

While a large number of audit studies have been carried out to examine the joint provision impact on auditor independence, there has been a disparity among these studies on how to measure such an impact. One approach that has been employed to assess the joint provision impact was to examine the relationship between the concurrent provision of NAS and audit firm's tenure. The idea is that since the joint provision strengthens auditors' economic bond with the client, and hence the economic loss in case of dismissal by the client, this joint provision may place a greater pressure on the external audit firm to submit to the client's inclinations (e.g., DeAngelo, 1981; Simunic, 1984; Firth 1997; Schneider, Church, \& Ely, 2006). It follows that auditors facing this kind of situations will be more willing to submit to the client's wishes (e.g., becomes less independent), and hence will be less likely to be changed by the audit client. This idea seems to be a plausible one, especially in light of findings reported in the audit literature 
suggesting that auditors are more sensitive to client's pressures during the early years of audit engagement as they are still in the course of recovering their start-up costs (Iyer \& Rama, 2004). Following this avenue of research, the current study attempts to assess the effect of the joint provision on auditors' independence by examining whether the joint provision is associated with more incidences of audit firms being tenured by the audit client in the Kuwaiti audit market.

Another interesting stream of the joint provision line of research was involved in investigating factors related to clients' purchase of NAS from their audit firms (e.g., Parkash \& Venable, 1993; Firth, 1997; Frankel, Johnson \&, Nelson, 2002; Ashbaugh, LaFond, \& Mayhew, 2003; Ruddock \& Taylor, 2005; Hay et al., 2006; Habib \& Islam, 2007). The review of this literature indicates that there has been very little research examining this issue in the developing countries settings. In an effort to expand this stream of audit research, the current study examines whether evidence about the determinants of audit clients' purchase of NAS documented in the developed countries' settings is applicable to a small developing country's market like the Kuwaiti audit market.

The current study is motivated by the scarcity of empirical research examining the potential impact of the joint provision of audit and NAS to audit clients on external auditors' independence in the developing countries' settings. While the audit literature is sated with studies examining the potential impact of the joint provision on auditor independence, most of these studies stem from Western and English-speaking counties (especially, the US, and the $\mathrm{UK}$ ), and to date, research examining this important issue is still limited in the developing countries' settings, and is virtually absent in the context of the Middle Eastern region. In addition, research examining audit tenure as a test of auditor independence is relatively little worldwide (Wang \& Hay, 2013), and rare, if any, in developing countries' settings (Wu \& Ying, 2016). Moreover, and as indicated below, findings of prior research about the relationship between the joint provision and audit firm tenure are mixed and still inconclusive. It appears, therefore, that reexamining this research issue is expected to be valuable in extending the audit literature by providing evidence about the effect of the joint provision on audit firm tenure from a developing country's setting, which is the aim of the current study.

The results of the current study reveal a negative association between clients' purchase of NAS from their audit firms an external audit firm tenure. This finding is suggestive that the joint provision does not lead to compromising auditor's independence. The current study's empirical results also reveal a positive relationship between audit client's purchase of NAS form their external audit firm and both the amount of audit fees and client's financial leverage.

The remainder of the current study proceeds as follows. Section 2 provides some review of related previous research. Section 3 provides information about the study's data and research methodology. The study's results are presented in Section 4, while section 5 provides concluding remarks about the study.

\section{LITERATURE REVIEW}

\section{The Joint Provision and Auditor Tenure}

The joint provision of NAS to audit clients and the potential impact of that on audit quality (e.g., independence) has been one of the most examined issues in the audit literature for the last three decades. While studies in this stream of research have typically been interested in determining whether the concurrent supply of NAS to audit clients leads to harming auditor independence, these studies have used different ways for measuring the joint provision impact on auditor independence. For example, some studies (e.g., Barkess \& Simnett, 1994; Wines, 1994; Craswell, 1999; Lennox, 1999) have tested whether the supply of NAS to audit clients is associated with less incidences of a qualified audit report, as a proxy of compromised auditor independence. Other studies (Sharma, 2001; Sharma \& Sidhu, 2001; DeFond, Raghunandan, \& Subramanyam, 2002; Geiger \& Rama, 2003) have tried to examine the independence issue by testing whether the joint supply is significantly related to decreased likelihood of a going-concern opinion. A different group of audit studies investigated the joint provision impact on auditor independence through examining the association between such joint provision and audit report lags (e.g., Knechel \& Payne, 2001; Knechel \& Sharma, 2008; Knechel, Sharma, \& Sharma, 2012). Another group of studies in this line of research, which are of more interest 
to the current study, has used the length of auditor tenure as a measure of the effect of the joint supply on auditor independence. The argument held by these studies is as follows: when the audit firm provides both audit and NAS to the audit client, the economic loss resulting from dismissal is potentially greater than if only audit services are provided (Simunic, 1984; Beck, Frecka, \& Solomon, 1988a; Hillson \& Kennelley, 1988). This issue has been investigated by several audit studies hypothesizing that audit firms providing both audit and NAS to the same client may be more likely to comply with client's demands (i.e., compromise their independence) in order to ensure being tenured by the client (Beck et al., 1988b; DeBerg, Kaplan, \& Pany,1991; Barkess \& Simnett, 1994; Hay et al., 2006).

Beck et al (1988a), for example, were among the earliest to discuss the relation between the joint provision of NAS and auditor tenure. In this article, the authors analytically demonstrated that the present value of the economic rents stemming from the joint provision (e.g., knowledge spillover) is lower in recurring audit engagement than in nonrecurring engagements. The authors argued that this makes the economic bond between the auditor and the audit client greater in earlier engagement years than in later ones. This elevated economic bond is said to provide auditors with an incentive to retain the audit client, and thus results in pressures to compromise their independence. In a related paper, Beck et al. (1988b) used a sample of US audit engagements to empirically examine of the relation between the joint provision of NAS and auditor tenure. Consistent with the incremental economic bonding hypothesis, the results of this study indicated that audit tenure is longer when NAS is provided by the incumbent audit firm ${ }^{1}$. DeBerg et al. (1991) performed a similar investigation by examining the relation between auditor change and the purchase of NAS using a sample of audit clients changing auditors (change group) and a matched sample of audit clients not changing auditors (non-change group). The results of this study indicated that the level of total, recurring, and nonrecurring NAS purchased were not significantly different between the change group and the non-change group. This study's findings, therefore, showed no evidence of an association between auditor change and the provision of NAS. Barkess and Simnett (1994) used a sample of Australian listed companies to examine, among other things, whether there is a relation between auditor tenure and the provision of NAS to audit clients. The results of this study revealed no evidence of a significant relationship between auditor tenure and the amount of NAS purchased. Using data related to U.S. audit engagements during the 2000-2002 period, Ghosh, Kallapur, \& Moon (2006) carried out a similar study by examining the relation between auditor tenure and the provision of NAS. This study's results showed a significant positive relationship between auditor tenure and the NAS fee ratio ${ }^{2}$. Hay et al. (2006) further investigated this issue in the New Zealand audit market by examining whether the provision of NAS to audit clients is associated with the length of auditor tenure. The results of this study indicated no significant relationship between auditor tenure and the provision of NAS. Ye et al. (2011) performed similar examination in the Australian market. Their results showed a significantly positive relationship between audit firm tenure and audit client's purchase of NAS. Using a sample of publically listed New Zealand firms, Wang and Hay (2013) recently examined the relationship between the joint provision of NAS to audit clients and audit tenure. Their results revealed no evidence of such a relationship.

It appears, therefore, that findings of prior research about the relationship between the joint provision and audit firm tenure are still inconclusive. The current study aims at extending this literature by further examining whether there is a significant effect of the joint provision on audit firm tenure using data related to a sample of audit engagements form the Kuwaiti audit market.

\footnotetext{
${ }^{1}$ The results of tenure differences, however, were small, and held for only one year of the analyzed period of three years.

${ }^{2}$ The authors, however, interpreted this positive relationship to be a result of economic efficiencies from auditor's increased knowledge about the audited firm rather than an auditor-management 'collusion behavior'.
} 


\section{Factors Influencing the NAS Purchase}

The audit literature includes a stream of research that has been interested in studying factors that influence audit clients' purchase of NAS from their external auditors (Parkash \& Venable, 1993; Firth, 1997; Frankel et al., 2002; Ashbaugh et al., 2003; Ruddock \& Taylor, 2005; Hay et al., 2006; Habib \& Islam, 2007).

In the US, Parkash and Venable (1993) were among the earliest to examine audit clients' NAS purchase behavior. Using data related to Fortun-500 companies, they examined and found evidence of a significant relationship between the amount of NAS purchased and audit clients' potential agency costs. Frankel et al. (2002) examined, among other things, factors influencing clients' purchase of NAS from external auditors. Their results indicated that poorly performing audit clients, as measured by ROA and stock returns, purchase more NAS, and that clients purchase of NAS is higher when the auditor is a Big-5 audit firm. Ashbaugh et al. (2003) performed a similar examination. Their results indicated, among other things, that the amount of NAS is higher when the audit client's leverage is high, and when the audit firm is a Big-5 one.

Ruddock and Taylor (2005) investigated the joint provision impact on audit firm's tenure in the Australian market. Their results indicated that the level of NAS purchased is negatively related to audit client's profitability, as well as the proportion of assets in the form of inventory and receivables, but is positively related to client's size. Firth (1997) used data related to UK audits to examine the relationship between the amount of NAS purchased and proxies of audit clients' agency costs. He found evidence that audit clients with higher agency costs tend to purchase lower levels of NAS, presumably in an effort to reassure their auditors' independence.

Habib and Islam (2007) study is among the very few studies that examined the determinants of the NAS purchase in a developing-country audit market. Using data related to audit engagements in Bangladesh, this study investigated factors that influence the audit client's decision to purchase NAS. The findings of this study showed that the amount of NAS purchased are higher for larger audit clients, clients with high liquidity, clients with multinational subsidiaries, clients audited by audit firms with international links, while is lower for clients with high leverage.

Using data related to 322 Swedish Small and Medium-sized Enterprises (SMEs), Svanström and Sundgren (2012) further examined this issue. Their results showed that audit clients' purchase of NAS from audit firms is positively associated with the length of the auditor-client relationship. Their results also showed that clients' purchase of NAS is not derived by the agency cost variables.

Although prior research's findings are inconclusive, they suggest that the level of NAS purchase is positively related to client's size and leverage, and is negatively related to the client's profitability.

\section{RESEARCH METHODOLOGY}

\section{The Provision of NAS and Auditor Tenure}

As indicted, one objective of the current study is to examine whether the auditor tenure, as a manifestation of auditor independence, is influenced by the concurrent provision of NAS to the audit client. To test such a research question, the current study uses a logistic regression model that is based on prior audit research (e.g., Hay et al., 2006; Wang \& Hay, 2013). In particular, the following model is used to examine whether there is a significant relation between jointly providing NAS to the audit client and audit firm's tenure:

$$
\text { TENURE }=b 0+b 1 \text { NAS_RATIO }+b 2 \text { LnSIZE }+b 3 \text { ROE }+b 4 \text { CURRENT }+b 5 \text { DEBT }++b 6 \text { LOSS }+e
$$

Where:

TENURE : a dummy variable, taking the value of one if the audit firm is tenured for three or more years, and zero otherwise;

NAS_RATIO : the ratio of NAS fee to the sum of audit and NAS fees, if any, paid to the audit firm.

SIZE $\quad$ : natural log of the audit client's total assets; 


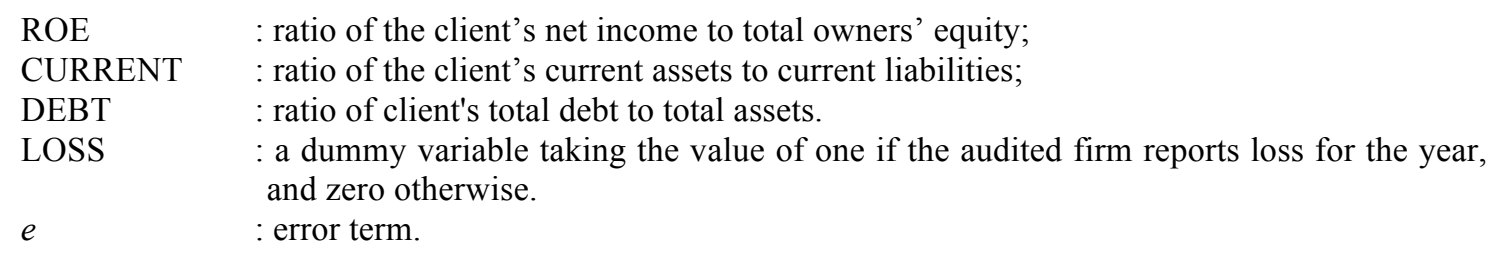

The dependent variable (TENURE) is a dichotomous variable that takes the value of one if the audit firm is tenured for two or more years and zero if not. As shown, the independent variables in the model include the ratio of NAS fees to the sum of audit and NAS fees, if any, paid to the audit firm (NAS_RATIO), the natural log of the audit client's total assets (SIZE), the client's return on equity (ROE), the client's current ratio (CURRENT), and the debt-to-assets ratio (DEBT) of the audit client, and a dichotomous variable indicating whether the audited firm is incurring a loss (LOSS). The experimental variable of particular interest is the NAS_RATIO variable. This variable is used to examine whether jointly providing NAS to audit clients is influential in audit firm's tenure. If the provision of NAS to audit clients has an influence on auditor independence, and hence is associated with more incidences of auditor tenure, then we would expect the NAS_RATIO variable to have a significantly positive regression coefficient.

\section{Factor Influencing NAS Purchase}

The second objective of the current study is to examine factors that influence audit client's purchase of NAS from their audit firms. To examine this question, the following logistic regression model is used ${ }^{3}$ :

$$
N A S=b 0+b 1 A U D_{-} F E E+b 2 C O M P L E X+b 3 S I Z E+b 4 R O E+b 5 D E B T+e
$$

Where,
NAS
: is a dichotomous variable taking the value of one if the audit client concurrently
AUD_FEE
COMPLEX purchases NAS from the audit firm, and zero otherwise.
COMPLEX
SIZE
: the natural log of audit fees;
ROE
: audit complexity measured as (inventory + Acc. Receiv.) / Total Assets
DEBT
: natural log of the audit client's total assets;
: ratio of the client's net income to owners' equity;
: ratio of client's total debt to total assets.
$e$
: error term.

As indicated from the model, the dependent variable (NAS) is a dichotomous variable taking the value of one if the audit client concurrently purchases NAS from their audit firms, and zero otherwise. This measure is used to examine whether the audit client's purchase of NAS is influenced by the independent variables included in the model. These variables are included in the model based on prior research findings that NAS purchase is significantly related to the amount of audit fees paid to the audit firm (e.g., Barkess \& Simnett, 1994), client's complexity of transactions (e.g., Hay et al., 2006), client's size (e.g., Geiger \& Rama, 2003; Hay et al., 2006), and client's risk (Hay et al., 2006). The AUD_FEE variable is a measure of the amount of audit fees paid by the audit client. The COMPLEX variable is a measure of audit client complexity. The SIZE variable is the natural log of client's total assets, and is used to measure client's size. The ROE is the ratio of the client's net income to owners' equity, while the DEBT variable is the ratio of the client's total debt to total assets, and both variables are used as measures of client's risk.

\section{Data}

The data used in the current study was collected by contacting six audit firms operating in the Kuwaiti audit market. A data gathering form was directed to contact names (e.g., partners or audit mangers) working in each audit firm, and was asked to provide the requested information about a random sample of 15 audit engagements performed by their

\footnotetext{
${ }^{3}$ This model is based on prior auditing research examining factors influencing the purchase of NAS (e.g., Parkash and Venable, 1993; Firth, 1997; Frankel et al., 2002; Ashbaugh et al., 2003; Ruddock and Taylor, 2005).
} 
audit firm. The data gathering form included items designed to gather, among other things, data related to variables needed for the current study. These variables included the amount of non-audit fees paid by the audit client to their audit firms, the length of the auditor-client relationship, in addition to audit client's financial statement information. Overall, data related to 57 engagements were received, representing 63 percent of the initial sample. Due to some missing data, however, observations related to 14 audit engagements were excluded from the study sample, resulting in a final sample of 43 engagements.

\section{RESULTS}

\section{Descriptive Statistics}

Table 1 shows descriptive statistics of the study's sample of audit engagements. As shown, the mean total assets of audited firms included in the study's sample is about KD96 million (approximately $\$ 317$ million) ${ }^{4}$. Compared to other related studies conducted in other countries (e.g., US., Australia, New Zealand), it seems that the sampled Kuwaiti firms are somewhat smaller. The results reported in Table 1 also show that the mean ratio of NAS fees to the sum of audit and NAS fees is about 38 percent, excluding observations with zero non-audit fees. The descriptive results also indicate that the liquidity of the sampled audited firms, measured by the current ratio, ranged from .19 to 52.3, with a mean current ratio of 1.14. Table 1 also shows descriptive statistics about the dichotomous variables included in the regression model. As shown, in about 80 percent of the sampled audit engagements, audit firms were tenured for three or more years, while were hired for two or less years in the remaining audit engagements. The table also shows that about 93 percent of the audited firms included in the study sample reported a profit, and only 7 percent were incurring a loss. Table 1 additionally shows that only 11.5 percent of the audited firms included in the sample concurrently purchased NAS from their auditors, while the rest hiring audit firms for financial statement audit only.

Panels A and B in Table 2 provides the Pearson correlations among the dependent and independent variables used in the models 1 and 2, respectively. As Panel A in Table 2 shows, correlations between the independent variables in model 1 are fairly low, with the highest below 0.40 , and with only two correlation coefficients that are statistically significant. Panel B in Table 2 shows the correlations between the independent variables in model 2. Although some of the correlations between the independent variables is somehow high, with the highest equal 0.691 between the AUD_FEE and SIZE variables, they are all below 0.80, and therefore should not pose concerns of biased regression estimates (Judge, Hill, Griffiths, Lutkepohl, \& Lee, 1988).

Table 1. Descriptive statistics $(n=43)$

\begin{tabular}{l|c|c|c|c}
\hline \multicolumn{1}{c|}{ Continuous Variables } & Minimum & Maximum & Mean & S. D. \\
\hline NAS_RATIO* & 0.25 & 0.69 & 0.384 & 1.8047 \\
\hline Non-audit Services Fees (KD)* & 1,000 & 5,000 & 3,150 & 1799 \\
\hline Audit Fees (KD) & 500 & 15,000 & 3,821 & 0.29872 \\
\hline COMPLEX & 0.00 & 0.97 & 0.367 & $183,829,048$ \\
\hline Total Assets (KD) & 140,080 & $772,016,000$ & $96,396,508$ & 4.63027 \\
\hline ROE & -0.14 & 29.26 & 1.4914 & 7.97116 \\
\hline CURRENT & 0.19 & 52.35 & 4.1437 & 0.2222 \\
\hline DEBT & 0.08 & 0.9 & 0.4142 & \\
\hline Dichotomous Variables & Value & Frequency & $\%$ & \\
\hline TENURE & 0 & 9 & 21 & 79 \\
\hline \multirow{2}{*}{ LOSS } & 1 & 34 & 93 & 7 \\
\hline \multirow{2}{*}{ NAS } & 0 & 40 & 88.4 & 11.6 \\
\hline
\end{tabular}

* excluding observations with zero non-audit fees.

\footnotetext{
${ }^{4}$ At the time the current empirical analysis was conducted, the currency exchange rate was approximately $\mathrm{KD} 1=\$ 3.30$. 
Table 2. Pearson Correlation

\begin{tabular}{l|c|c|c|c|c|c|c}
\hline Panel A: & Tenured & NAS_RATIO & SIZE & ROE & Current & DEBT & LOSS \\
\hline TENURE & 1 & & & & & \\
\hline NAS_RATIO & 0.122 & 1 & & & & \\
\hline SIZE & -0.189 & 0.090 & 1 & & & \\
\hline ROE & -0.102 & -0.039 & $-.337^{*}$ & 1 & & \\
\hline CURRENT & 0.005 & -0.114 & -0.072 & -0.052 & 1 & 1 \\
\hline DEBT & -0.264 & $.396^{* *}$ & 0.078 & 0.217 & -0.250 & \\
\hline LOSS & -0.141 & -0.091 & 0.098 & -0.093 & -0.024 & -0.246 & 1 \\
\hline
\end{tabular}

Panel B:

\begin{tabular}{l|c|c|c|c|c|} 
& NAS & AUD_FEE & COMPLEX & SIZE & \\
\hline NAS & 1 & & & \\
\hline AUD_FEE & 0.218 & 1 & & \\
\hline COMPLEX & -0.004 & $-0.381^{*}$ & 1 & \\
\hline SIZE & 0.135 & $0.691^{* *}$ & $-0.446^{* *}$ & 1 & \\
\hline ROE & -0.028 & -0.174 & 0.279 & $-0.337^{*}$ & \\
\hline DEBT & $0.368^{*}$ & -0.132 & 0.105 & 0.078 & 0.217 \\
\hline
\end{tabular}

*,** Correlation is significant at the $0.05,0.01$ levels, respectively (2-tailed).

\section{EMPIRICAL RESULTS}

Table 3 provides the results of model 1, the Audit Tenure logistic regression. As Table 3 shows, the overall percentage of correct classification of cases provided by the model is about 61 percent, and the model's Chi-square is 27.531 and is significant ( $\mathrm{p}$-value $<.000)$. As shown in this table, the regression coefficient of the NAS_RATIO variable, which is used to examine the relation between the non-audit services provided to the audit client and audit firm's tenure, is statistically significant ( $\mathrm{p}$-value $<.047$ ), but contrary to expectation has a negative sign $^{5}$. Such a result not only do not provide support for the research hypothesis of a positive relationship between the provision of NAS to audit clients and audit firm's tenure, but also indicate that in general the audit relation between audit clients and audit firms is shorter when the audit firm provides both audit and NAS. The results in Table 3 also indicate that the regression coefficients of the SIZE variable is statistically significant (p-value $<.004)$ and has a positive sign, indicating the audit firm tenure is more common for larger firms. This result is consistent with findings reported in prior related research (e.g. Geiger \& Rama, 2003; Hay et al., 2006) of a positive relationship between audit firm tenure and the size of the audited firm. The results in Table 3 also show that the regression coefficients of the ROE and DEBT independent variables have positive signs and are both statistically significant, suggesting that firms with higher profitability and with higher leverage tend to keep their audit firms more often. These results are somehow problematic in the sense that audit client's profitability and leverage were used as measures of client's risk, and that while high profitability indicate lower risk, high leverage indicate higher risk. Such results also suggest that client's profitability and leverage in similar contexts might not be mere proxies for client risk, and that they should be looked at as two separate constructs. As indicated in Table 3, the regression coefficients of the CURRENT and LOSS control variables are statistically insignificant.

\footnotetext{
${ }^{5}$ Although the negative sing of the regression coefficient contradicts with the study's prediction of a positive sign, such a result is similar to results reported in other prior related studies (e.g. Hay, 2006; Wang and Hay, 2013).
} 
Table 3. The "Audit Tenure" Logistic Regression Results

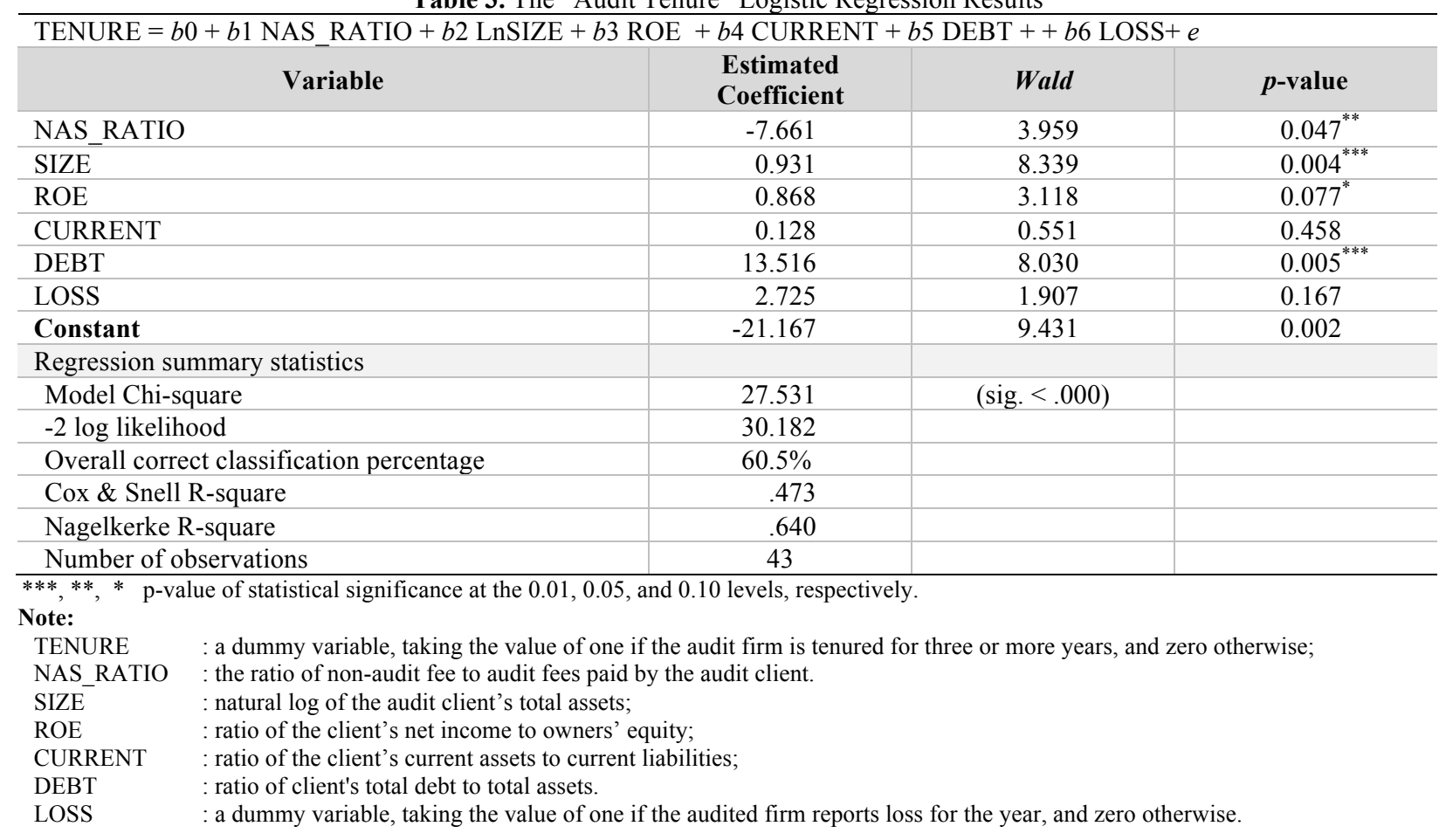

Table 4 shows that results of model 2, the NAS Purchase logistic regression. As this table shows, the overall percentage of cases classified correctly by the model is about 88 percent. The model's Chi-square is 19.334 and is significant (pvalue < .002). The regression coefficients of the AUD_FEE independent variable is positive and is statistically significant at the 0.10 level ( $\mathrm{p}$-value $<.093$ ). This result indicates that audit client's purchase of NAS from their audit firms is positively related to the level of audit fees. One possible explanation of such a positive relationship is that the amount of audit fees paid to audit firms represents the quality of their professional services. The regression coefficient of the DEBT independent variable is also positive and is statistically significant (p-value $<.032$ ). This result suggests that firms with higher financial leverage tend to concurrently purchase NAS from their audit firms more often, and is consistent with findings reported in prior related studies (e.g., Ashbaugh et al., 2003). As the results in Table 4 show, the regression coefficients of the COMPLEX, SIZE, and ROE independent variables are statistically insignificant. 
Table 4. The "NAS Purchase" Logistic Regression Results

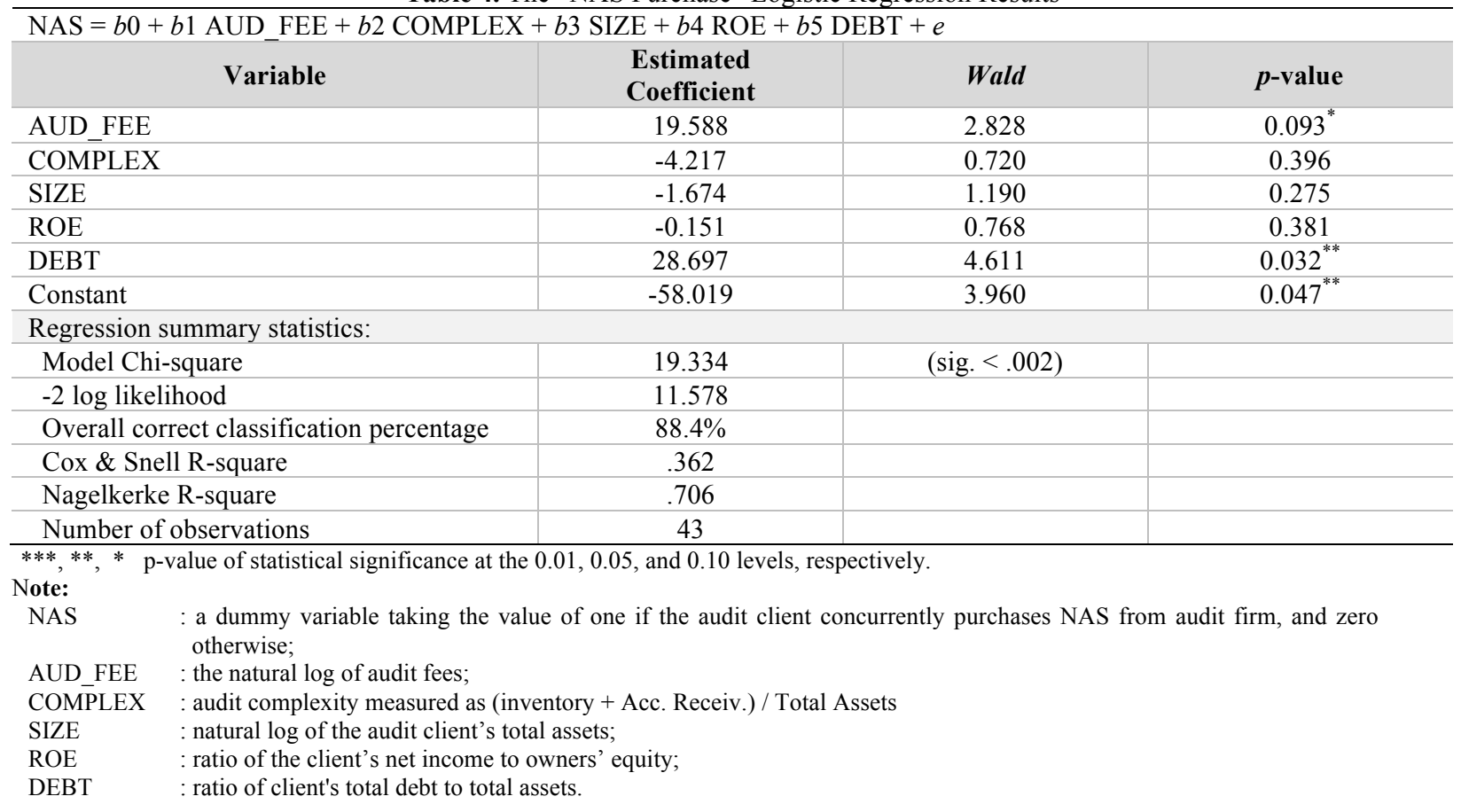

\section{Sensitivity Analysis}

To check the robustness of the results found using the original NAS purchase regression model, a sensitivity analysis is performed. In particular, a new variable, NAS_FEE representing the natural log of NAS fees is used as a measure of the model's dependent variable. The new regression model is re-run, and the results obtained from this new research model are provided in Table 5. As shown from this table, the model is generally significant ( $\mathrm{p}$-value $<.061$ ), and the $\mathrm{R}^{2}$ of the new model is .24 . The results obtained from the new NAS regression model show that the regression coefficients of the ROE and the DEBT independent variables are both positive and statistically significant at the 0.05 significance level. This suggests audit clients with higher profitability tend to concurrently purchase higher amounts of NAS from their audit clients. The results also suggest the same when audit client has a high financial leverage. Unlike results obtained from the original "NAS purchase" logistic regression model, the results show that the AUD_FEE variable is statistically insignificant. One possible explanation for these different results is that the amount of audit fees paid to audit firms might be influential in audit client's decision to purchase NAS, but not the amount of these services. The results form Table 5 also indicate that, like in the original model, the COMPLEX and SIZE variables are statistically insignificant. 
Table 5. The "NAS Purchase" OLS Regression Results

\begin{tabular}{|c|c|c|c|c|c|}
\hline Variable & Coefficient & $\begin{array}{c}\text { Standard } \\
\text { Error }\end{array}$ & $t$-statistic & $p$-value & VIF \\
\hline Intercept & -3.326 & 1.876 & -1.772 & $0.085^{*}$ & \\
\hline AUD_FEE & 0.160 & 0.612 & 0.262 & 0.795 & 1.310 \\
\hline COMPLEX & -0.111 & 0.119 & -0.940 & 0.354 & 2.487 \\
\hline SIZE & -0.034 & 0.039 & -0.888 & 0.380 & 1.265 \\
\hline ROE & 2.342 & 0.785 & 2.984 & $0.005^{* *}$ & 1.190 \\
\hline $\begin{array}{l}\text { DEBT } \\
\text { Model: } \\
\text { R-Square }=.240 \\
\text { F-statistic }=2.338 \\
\quad \text { Signif. } \mathrm{F}<.061 \\
\mathrm{n}=43\end{array}$ & 1.337 & 0.656 & 2.038 & $0.049^{* *}$ & 2.130 \\
\hline \multicolumn{6}{|c|}{$\begin{array}{l}* * * * \text { p-value of statistical significance at the } 0.05 \text {, and } 0.10 \text { levels, respectively } \\
\text { Note: }\end{array}$} \\
\hline $\begin{array}{ll}\text { NAS_FEE } & \text { : the natura } \\
\text { AUD_FEE } & \text { : the natura } \\
\text { COMPLEX } & : \text { audit com } \\
\text { SIZE } & \text { : natural lo } \\
\text { ROE } & : \text { ratio of th } \\
\text { DEBT } & \text { : ratio of cll }\end{array}$ & $\begin{array}{l}\text { AS fees; } \\
\text { dit fees; } \\
\text { asured as (inve } \\
\text { dit client's total } \\
\text { let income to ov } \\
\text { debt to total ass }\end{array}$ & $\begin{array}{l}\text { Acc. Receiv. } \\
\text { quity; }\end{array}$ & Assets & & \\
\hline
\end{tabular}

\section{SUMMARY AND CONCLUSION}

The question of whether auditors' independence is compromised when the audit firm provides NAS to their audit clients has been a subject of debate among audit professionals, regulators, and researchers for a long period of time and in several countries. Audit firm's joint provision of NAS to audit clients has provoked concerns about the potential impact of that on the soundness of auditors' independence.

Although the audit literature is replete with research conducted to examine the impact of the joint provision impact on auditor independence, there has been a scarcity of and a need for carrying out research to investigate this issue in the developing countries settings (Wu \& Ying, 2016). Moreover, empirical research electing to examine audit firm tenure as a test of the joint provision's impact on audit independence has been very little, if any, outside the context of developed English-speaking counties. Likewise, empirical evidence about the determinants of audit clients' purchase of NAS has been rare outside the Western countries' audit markets. Therefore, the current study aims at filling this gap in prior research by providing empirical evidence about these important research questions in a developing country's context. In particular, the current study uses a sample of Kuwaiti audit engagements to perform two research examinations. First, the current study tests the association between the joint provision of audit and non-audit services to the audit client and the incidences of audit firm's tenure, as a proxy for auditor independence. Secondly, the present study investigates factors that influence firms' purchase of NAS from their external auditors.

The study's results in general show that the joint provision of audit and NAS to audit clients is not associated with longer audit tenure. In fact, the results reveal a negative relationship between the joint provision and audit tenure. The negative relationship between the joint provision and audit firm's tenure suggests that providing NAS do not lead to harming external auditors' independence. The study' results also indicate that audit client's purchase of NAS from their audit firms is positively related to the amount of audit fees paid, and the client's financial leverage.

The current study is subject to several limitations. First, the study's sample is relatively small, which has inevitably led to weakening the statistical power of the tests applied. Therefore, further research with larger sample sizes needs to be conducted in developing countries' settings to validate the research findings reported in the current study. Secondly, the dependent variable, TENURE, is a dichotomous variable, and hence does not provide insight about the effect of the length of audit tenure. Future similar research therefore could be conducted to examine this research issue using continuous dependent variables reflecting the years of audit tenure. The current study uses audit tenure as a measure of audit independence when investigating the effect of the joint provision. Future research is also needed to 
re-examine the joint provision impact on audit independence in the context of developing countries other measures, such as incidences of qualified or modified audit opinion, going-concerns opinions, or audit report lags.

\section{AUTHOR BIOGRAPHY}

Meshari Al-Hajri earned his Ph.D. in accounting from the University of Arkansas, US. He is an associate professor in the Department of Accounting at Kuwait University. His main research interests include audit markets, capital markets, corporate governance, and corporate social responsibility.

\section{REFERENCES}

Ashbaugh, H. R. LaFond \& Mayhew, B. W. (2003). Do non-audit services compromise auditor independence? Further evidence. The Accounting Review, 78(3), 611-639.

Barkess, L. \& Simnett, R. (1994). The provision of other services by auditors: Independence and pricing issues. Accounting \& Business Research, 24(94), 99-108

Basioudis, I. G., Papakonstantinou, E. \& Geiger, M. A. (2008). Audit fees, non-audit fees and auditor going-concern reporting decisions in the United Kingdom. Abacus, 44(3), 284-309.

Beck, P., Frecka, T. J. \& Solomon, I. (1988a). A model of the market for MAS and audit services: Knowledge spillovers and auditor-auditee bonding. Journal of Accounting Literature, 7(1), 50-64.

Beck, P., Frecka, T. J. \& Solomon, I. (1988b). An empirical analysis of the relationship between MAS involvement and auditor Tenure: Implications for auditor independence. Journal of Accounting Literature, 7(1), 65-84.

Craswell, A. (1999). Does the provision of non-audit services impair auditor independence? International Journal of Auditing, $3(1), 29-40$.

Davis, S. M. \& Hollie, D. (2008). The Impact of non-audit service fee levels on investors' perception of audit independence. Behavioral Research in Accounting, 20(1), 31-44.

DeAngelo, L. (1981). Auditor independence, low-balling, and disclosure regulation. Journal of Accounting and Economics, 3(2), 113-127.

DeBerg, C., Kaplan, S., \& Pany, K. (1991). An examination of some relationships between non-audit services and auditor change. Accounting Horizons, 5(1), 17-28

DeFond, M, Raghunandan, K., \& Subramanyam, K. (2002). Do non-audit service fees impair auditor independence? Evidence from going concern audit opinions. Journal of Accounting Research, 40(4), 1247-1274.

Firth, M. (1997). The Provision of Non-audit Services by Accounting Firms to their Audit Clients, Contemporary Accounting Research, 14(2), 1-21.

Frankel, R. M., Johnson, M. F., Nelson, K. K. (2002).The Relation between auditors' fees for non-audit services and earnings management. Accounting Review, 77(1), 71-105.

Ghosh, A., Kallapur, S. \& Moon, D. (2006). Provision of non-audit services by auditors economic efficiency or managerial opportunism? Research Paper Series, Centre for Analytical Finance, Indian School of Business.

Geiger, M., \& Rama, D. (2003). Audit fees, non-audit fees, and auditor reporting on stressed companies. Auditing: A Journal of Practice \& Theory, 22(2), 53-69.

Habib, A., \& Islam, A. (2007). Determinants and consequences of non-audit service fees preliminary evidence from Bangladesh. Managerial Auditing Journal, 22(5), 446-469.

Hay, D., Knechel, R. \& Li, V. (2006). Non-audit services and auditor independence: New Zealand evidence. Journal of Business Finance \& Accounting, 33(5/6), 715-734.

Hillson, W. \& Kinnelley, M. (1988). The economics of non-audit services. Accounting Horizons, 2(3), 32-40.

Iyer, V. M. \& Rama, D.V. (2004). Clients' expectations on audit judgments: A note. Behavioral Research in Accounting, 16(1), 63-74.

Judge, G., Hill, R., Griffiths, W., Lutkepohl, H., \& Lee, T. (1988). Introduction to the theory and practice of Econometrics. NY: Wiley, New York.

Klumpes, P., Komarev, I., \& Eleftheriou, K. (2016). The pricing of audit and non-audit services in a regulated environment: A longitudinal study of the UK life insurance industry. Accounting and Business Research, 46(3), 278-302.

Knechel, W. R. \& Payne, J. L. (2001). Additional evidence on audit report lag. Auditing: A Journal of Practice and Theory, 20(1), 137-146.

Knechel, W. R. \& Sharma, D. S. (2008). Auditor provided non-audit services and audit effectiveness and efficiency: Evidence from pre-and post-SOX audit report lags. Auditing: A Journal of Practice \& Theory, 31(4), 85-114.

Knechel, W. R., Sharma, D.S., \& Sharma, V. D. (2012). Non-audit services and knowledge spillover: Evidence from New Zealand. Journal of Business Finance \& Accounting, 39(1\&2), 60-81.

Lennox, C. (1999). Non-audit fees, disclosure of audit quality. The European Accounting Review, 8(2), 239-252.

Levitt, A. (2000). Renewing the covenants with investors. Remarks Delivered at the NYU Center for Law and Business, New York. 
Parkash, M., Venable, C. F. (1993). Auditee incentives for auditor independence: The case of non-audit services. Accounting Review, 68(1), 113-133.

Park, H., Choi, J., \& Cheung, J. (2017). Does non-audit services compromise audit quality? Journal of Applied Business Research, 33(2), 309-320.

Ruddock, C. \& Taylor, S. (2005). Non-audit services, audit fees and earnings management. Working paper, University of New South Wales, Kensington and Capital Markets CRC Ltd, Sydney.

Schneider, A., Church, B. K. \& Ely, K. M. (2006). Non-audit services and auditor independence: A review of literature. Journal of Accounting Literature, 25, 169-211.

Sharma, D. (2001). The association between non-audit services and the propensity of going concern qualifications: Implications for audit independence. Asia-Pacific Journal of Accounting \& Economics, 8(2), 143-456.

Sharma, D., \& Sidhu, J. (2001). Professionalism vs. Commercialism: The association between non-audit services (NAS) and audit independence. Journal of Business Finance \& Accounting, 28(5/6), 595-629.

Simunic, D. A. (1984). Auditing, consulting, and auditor independence. Journal of Accounting Research, 22(2), 679-702.

Svanström, T., \& Sundgren, S. (2012). The demand for non-audit services and auditor-client relationships: Evidence from Swedish small and medium-sized enterprises. International Journal of Auditing, 16(1), 54-78.

Wang, S., \& Hay, D. (2013). Auditor independence in New Zealand: Further evidence on the role of non-audit services. Accounting and Management Information Systems, 12(2), 235-262.

Wines, G. (1994), Auditor independence, auditor qualification and the provision of non-audit services: A note. Accounting and Finance, 34(1), 75-86.

Wu, H., \& Ying, S. (2016). Realizing auditor independence in China: Insights from the local context. Contemporary Management Research, 12(2), 245-272.

Ye, P., Carson, E., \& Simnett, R. (2011). Threats to auditor independence: The impact of relationship and economic bonds. Auditing: A Journal of Practice \& Theory, 30(1), 121-148. 